\title{
Perkecambahan dan pertumbuhan benih tomat (Solanum lycopersicum) akibat perlakuan berbagai dosis $\mathrm{NaOCl}$ dan metode pengeringan
}

\author{
(Germination and growth of tomato seeds (Solanum lycopersicum) due to the treatment of \\ various doses of $\mathrm{NaOCl}$ and the drying methods) \\ D. Purba, E. D. Purbajanti dan Karno \\ Agroecotechnology, Faculty of Animal and Agricultural Sciences, Diponegoro University \\ Tembalang Campus, Semarang 50275 - Indonesia \\ Corresponding E-mail:pakpakdenanda@gmail.com
}

\begin{abstract}
The purpose of the research was to study the concentration of $\mathrm{NaOCl}$ and drying method during the extraction process for germination and growth of tomato seedlings. This study used Completely Randomized Design with two factors with three replicates. The first factor was soaking the seeds with $\mathrm{NaOCl}$ concentrations: $\mathrm{NaOCl} 0 \%$ (control), $\mathrm{NaOCl} 6 \%, \mathrm{NaOCl} 9 \%$ and $\mathrm{NaOCl} 13 \%$. The second factor was the drying methods: without drying (control), natural drying and drying using oven. The parameters observed were germination, seed growth rate, maximum growth potential, leaf size, leaf area, plant height, plant growth rate and relative plant growth rate. The data were analyzed using variance analysis and continued by Duncan Multiple Range Test (DMRT) of 5\%. The result of variance analysis showed that immersion treatment using $\mathrm{NaOCl}$ and drying method had not given interaction during seed germination and seedling growth. Soaking with $9 \% \mathrm{NaOCl}$ showed the best result of germination process and seedling growth whereas the best drying method was naturally because it did not cause impermeability of seeds.
\end{abstract}

Keyword : Tomato, seed, drying, $\mathrm{NaOCl}$, seed viability

\begin{abstract}
ABSTRAK
Penelitian bertujuan untuk mengetahui pengaruh berbagai konsentrasi $\mathrm{NaOCl}$ dan metode pengeringan selama proses ekstraksi yang dilihat dari perkecambahan dan pertumbuhan bibit tanaman tomat. Penelitian ini menggunakan Rancangan Acak Faktorial Lengkap dengan dua faktor dan diulang sebanyak 3 kali. Faktor pertama adalah perendaman benih dengan konsentrasi $\mathrm{NaOCl}$ yaitu $\mathrm{NaOCl} 0 \%$ (kontrol), $\mathrm{NaOCl} 6 \%, \mathrm{NaOCl} 9 \%$ dan $\mathrm{NaOCl} 13 \%$. Faktor kedua adalah metode pengeringan yaitu tanpa pengeringan (kontrol), pengeringan alami dan pengeringan menggunakan oven. Parameter yang diamati adalah daya berkecambah, kecepatan tumbuh benih, potensi tumbuh maksimal, jumah daun, luas daun, tinggi tanaman, laju pertumbuhan tanaman dan laju pertumbuhan relatif tanaman. Data dianalisis menggunakan analisis ragam dan dilanjut dengan Uji Duncan Multiple Range Test (DMRT) taraf 5\%. Hasil analisis ragam menunjukkan bahwa perlakuan perendaman menggunakan $\mathrm{NaOCl}$ dan metode pengeringan tidak memberikan interaksi saat perkecambahan benih dan pertumbuhan bibit. Perendaman dengan $\mathrm{NaOCl} 9 \%$ merupakan hasil terbaik proses perkecambahan dan pertumbuhan bibit sedangkan metode pengeringan terbaik adalah secara alami karena tidak menyebabkan benih impermeabilitas.
\end{abstract}

Kata kunci : Tomat, benih, pengeringan, $\mathrm{NaOCl}$, viabilitas benih

\section{PENDAHULUAN}

Tomat (Solanum lycopersicum) merupakan salah satu komoditas hortikultura yang bernilai ekonomi tinggi dan sangat banyak digemari masyarakat. Buah tomat memiliki banyak manfaat 
dan mengandung vitamin yang sangat penting bagi tubuh manusia. Potensi pasar buah tomat juga dapat dilihat dari segi harga yang terjangkau oleh seluruh lapisan masyarakat sehingga membuka peluang yang lebih besar terhadap serapan pasar (Dalimartha, 2011). Berdasarkan data Badan Pusat Statistik (BPS, 2016) bahwa produksi tomat adalah sekitar 915.987 ton yang adalah menurun jika dibandingkan dengan produksi tahun 2015 yaitu 954.046 ton. Permintaan tomat di dunia semakin meningkat sehingga hal ini menjadi kesempatan bagi Indonesia untuk meningkatkan produktivitas tanaman tomat karena dapat membantu dalam meningkatkan taraf ekonomi Indonesia.

Peningkatan produksi tomat tidak terlepas dari faktor benih. Salah satu kendala penting dalam penyediaan benih adalah ekstraksi benih. Kegiatan ekstraksi tomat biasanya dilakukan dengan ekstraksi basah yaitu memisahkan biji tomat dari daging buah dan pulp sehingga menghasilkan benih yang bersih (Wartapa, 2009). Benih yang tidak diekstraksi dengan baik menyebabkan benih lama berkecambah, mudah terkontaminasi mikroba dan bahkan berdampak terhadap pertumbuhan vegetatif dan generatif tanaman (Rismunandar, 2001). Ekstraksi tomat yang tidak bersih dicirikan dengan lendir dan pulp yang masih tersisa pada biji tomat dan warna fisik kelihatan kuning kusam (Karavina, 2009). Benih tidak bersih dari pulpnya identik mudah terkena mikroba dan menyebabkan benih mudah busuk dan perkecambahannya lebih lama. Pulp yang melekat pada biji tomat mengandung asam absisat yang merupakan zat penghambat perkecambahan dan pertumbuhan benih (Wiguna, 2013).

Salah satu cara untuk mengekstraksi biji buah berdaging adalah menggunakan senyawa kimia $\mathrm{NaOCl}$ (Wiguna, 2013). Ekstraksi menggunakan $\mathrm{NaOCl}$ dapat membersihkan pulp dan lendir yang masih melekat pada biji tomat (Kartasapoetra, 2003). Penggunaan $\mathrm{NaOCl}$ tentunya menggunakan dosis yang tepat sehingga tidak menyebabkan kerusakan viabilitas benih. Wiguna (2013) dalam penelitiannya menggunakan $\mathrm{NaOCl} 5 \%$ saat mengekstraksi biji tanaman cabai dan menunjukkan hasil yang tampak lebih bersih. $\mathrm{NaOCl}$ merupakan salah satu senyawa kimia desinfektan yang memiliki kandungan klorida yang dapat meningkatkan permeabilitas kulit benih yang berfungsi untuk mempercepat proses perkecambahan (Ardiansyah, 2014). Hasil penelitian Nyoman (2016) menunjukkan bahwa perubahan fisik benih menjadi lebih bersih yaitu dengan perendaman biji tomat menggunakan $\mathrm{NaOCl}$ selama 15 menit.

Metode pengeringan juga mempengaruhi kualitas benih. Pengeringan yang biasa dilakukan masyarakat adalah pengeringan alami yaitu menggunakan sinar matahari, pengeringan menggunakan oven dengan suhu tertentu dan pengeringan menggunakan kipas angin (Surahman, 2012). Pengeringan benih dilakukan setelah kegiatan ekstraksi dengan tujuan untuk mengurangi kandungan air di dalam benih sebelum dikecambahkan atau disimpan (Surahman, 2012). Hasil penelitian Kuswanto (2003) menunjukkan viabilitas benih tomat hasil pengeringan secara alami lebih tinggi dibandingkan pengeringan oven. Penjemuran biji dengan sinar matahari merupakan salah satu cara pengeringan yang paling sederhana dengan temperatur suhu sekitar $27^{\circ} \mathrm{C}-32^{\circ} \mathrm{C}$ namun membutuhkan waktu 3-4 hari (Chanan, 2004). Pengeringan benih secara modern dapat dilakukan menggunakan oven dengan suhu $42^{\circ} \mathrm{C}$ yang hanya membutuhkan waktu 1 hari (Fauzah, 2014).

Penelitian ini bertujuan untuk mengetahui pengaruh ekstraksi dengan perendaman berbagai dosis $\mathrm{NaOCl}$ dan pengaruh metode pengeringan serta interaksi kedua faktor terhadap perkecambahan dan pertumbuhan bibit tomat.

\section{MATERI DAN METODE}

\section{Materi}

Penelitian ini telah dilaksanakan di lahan Screen House Taburmas, Bandungan pada bulan Maret - Juli 2017. Bahan-bahan yang digunakan dalam penelitian ini adalah buah tomat varietas Martha $12 \mathrm{~kg}$, larutan $\mathrm{NaOCl} 13 \%, \mathrm{NaOCl} 9 \%$, $\mathrm{NaOCl} 6 \%$, air , media tanam (kompos dan tanah). Alat yang digunakan dalam penelitian ini adalah polybag, cawan, timbangan analitik, Leaf Area Meter, gelas ukur, oven, cangkul, penggaris, alat tulis, tissue, kain saring, pisau, bak pengecambah benih, wadah tempat perendam biji tomat, label, gunting, spray, alat siram, amplop, plastik benih 


\section{Metode}

Penelitian ini dimulai dari pemilihan buah tomat, selanjutnya biji dipisah dari daging buah dengan memotong buah tomat dengan pisau kemudian didiamkan selama 1 malam. Biji yang masih mengandung banyak pulp direndam dengan larutan $\mathrm{NaOCl}(\mathrm{P} 0) \mathrm{NaOCl} 0 \%$, (P1) $\mathrm{NaOCl} 6 \%$, (P2) $\mathrm{NaOCl} 9 \%$, (P3) $\mathrm{NaOCl} 13 \%$. Perendaman dilakukan didalam wadah dan meletakkan pada tempat yang aman selama 15 menit. Setelah proses perendaman benih dicuci dan dikeringkan dibawah sinar matahari (D1), menggunakan oven (D2). Pengeringan dilakukan dibawah sinar matahari hingga benih kering.

Pengeringan menggunakan oven dilakukan pada suhu $45^{\circ} \mathrm{C}$ selama 1-2 hari. Pengeringan bertujuan untuk menghilangkan zat yang menempel pada benih tomat. Benih yang telah dikeringkan dikecambahkan pada bak pengecambah dan diamati hingga 2 minggu untuk mengetahui parameter kecambah benih. Sementara benih lain ditanam di polybag untuk pengamatan pertumbuhan hingga bibit. Penanaman dilakukan pada polybag dengan media tanam dan pupuk kandang. Pengamatan dilakukan hingga 5 minggu. Parameter perkecambahan yaitu daya kecambahan, potensi tumbuh maksimum kecambah dan kecepatan tumbuh benih. Parameter bibit tanaman tomat adalah laju pertumbuhan, laju pertumbuhan relatif tanaman, tinggi tanaman, jumlah daun dan jumlah benih tumbuh.

\section{Rancangan Percobaan dan Analisis Data}

Rancangan Percobaan penelitian ini adalah percobaan faktorial $4 \times 3$ dengan rancangan lingkungan yang digunakan adalah Rancangan Acak Lengkap (RAL). Faktor pertama yaitu perlakuan pemberian $\mathrm{NaOCl}(\mathrm{N})$ yang terdiri dari empat taraf perlakuan yaitu (P0) $\mathrm{NaOCl} 0 \%$, (P1) $\mathrm{NaOCl} 6 \%$, (P2) $\mathrm{NaOCl} 9 \%$, (P3) $\mathrm{NaOCl} \mathrm{13 \% .}$ Faktor kedua adalah metode pengeringan (D) yakni (D0) tanpa pengeringan, (D1) pengeringan alami /matahari, (D2) pengeringan buatan /oven. Analisis data dilakukan secara statistik berdasarkan prosedur analisis sidik ragam (uji F). Apabila terdapat pengaruh perlakuan, maka dilanjutkan dengan Duncan's Multiple Range Test pada taraf $5 \%$.

\section{HASIL DAN PEMBAHASAN}

\section{Daya Berkecambah Benih}

Hasil analisis ragam menunjukkan bahwa metode pengeringan berpengaruh nyata terhadap daya berkecambah benih dan dosis $\mathrm{NaOCl}$ berpengaruh nyata terhadap daya berkecambah benih tetapi tidak terdapat interaksi antara faktor pengeringan dan dosis $\mathrm{NaOCl}$. Data pengaruh metode pengeringan dan perendaman benih dengan konsentrasi $\mathrm{NaOCl}$ dapat dilihat pada Tabel 1.

Tabel 1 menunjukkan bahwa daya kecambah berbeda nyata pada perlakuan pengeringan yaitu pengeringan mengggunakan oven. Pengeringan menggunakan oven memiliki daya kecambah $58,66 \%$ adalah paling rendah. Rendahnya daya kecambah ini dikarenakan pengeringan menggunakan oven memiliki suhu yang tetap sehingga mempercepat pengeringan benih namun menyebabkan benih menjadi impermeabilitas yakni kulit luar benih mengeras sementara bagian

Tabel 1. Daya Berkecambah Benih Tomat dengan perlakuan berbagai Dosis $\mathrm{NaOCl}$ dan Metode Pengeringan

\begin{tabular}{|c|c|c|c|c|c|}
\hline \multirow[b]{2}{*}{ Perlakuan Pengeringan } & \multicolumn{5}{|c|}{ Daya Berkecambah Benih } \\
\hline & $\begin{array}{l}\mathrm{NaOCl} \\
0 \%\end{array}$ & $\begin{array}{l}\mathrm{NaOCl} \\
6 \% \\
\end{array}$ & $\begin{array}{l}\mathrm{NaOCl} \\
9 \% \\
\end{array}$ & $\begin{array}{l}\mathrm{NaOCl} \\
13 \% \\
\end{array}$ & $\begin{array}{l}\text { Rata- } \\
\text { rata }\end{array}$ \\
\hline & \multicolumn{5}{|c|}{------------------------------.\%o--------------------------- } \\
\hline Kontrol & 81,33 & 86,66 & 87,33 & 88,66 & $81,00^{\mathrm{a}}$ \\
\hline Alami & 78,66 & 92,66 & 96,66 & 88,66 & $81,75^{\mathrm{a}}$ \\
\hline Oven & 54,66 & 61,33 & 54,00 & 56,00 & $58,66^{\mathrm{b}}$ \\
\hline Rata-rata & $70,22^{b}$ & $75,77^{\mathrm{ab}}$ & $79,88^{\mathrm{a}}$ & $69,33^{\mathrm{b}}$ & \\
\hline
\end{tabular}

Keterangan : Superskrip yang berbeda pada kolom atau baris rata-rata menunjukkan berbeda nyata $(\mathrm{p}<0,05)$. 
dalam benih masih basah sehingga menghambat perkecambahan. Hal ini didukung oleh Hasanah (2002) yang menyatakan bahwa pengeringan dengan metode oven adalah pengeringan yang paling praktis karena memiliki suhu yang tinggi dan tetap sehingga pengeringan benih merata tetapi menyebabkan benih impermeabilitas yaitu bagian luar benih menjadi mengeras sementara bagian dalam benih masih basah. Keadaan seperti ini mengakibatkan kulit benih kedap air dan menghambat perkecambahan benih.

Perendaman benih menggunakan $\mathrm{NaOCl}$ dengan dosis 9\% memiliki daya berkecambah tertinggi yaitu $79,88 \%$. Daya berkecambah benih tomat dengan perendaman $\mathrm{NaOCl} 9 \%$ berbeda nyata dengan perlakuan $\mathrm{NaOCl}$ lainnya. Hal ini menunjukkan bahwa konsentrasi $\mathrm{NaOCl}$ 9\%

\section{Kecepatan Tumbuh Benih}

Hasil analisis ragam menunjukkan bahwa perlakuan konsentrasi $\mathrm{NaOCl}$ berpengaruh nyata terhadap kecepatan tumbuh benih sedangkan faktor pengeringan tidak berpengaruh nyata terhadap parameter kecepatan tumbuh benih serta tidak terdapat interaksi antara kedua faktor. Data pengaruh metode pengeringan dan perendaman benih dengan konsentrasi $\mathrm{NaOCl}$ dapat dilihat pada Tabel 2.

Berdasarkan Tabel 2 diketahui bahwa kecepatan tumbuh benih pada perlakuan konsentrasi $\mathrm{NaOCl} 9 \%$ adalah 68,25 merupakan nilai tertinggi dibanding perlakuan lainnya. Hal ini karena daya berkecambah benih memberikan pengaruh terhadap kecepatan tumbuh benih.

Tabel 2. Kecepatan Tumbuh Benih Tomat dengan perlakuan berbagai Dosis $\mathrm{NaOCl}$ dan Metode Pengeringan

\begin{tabular}{|c|c|c|c|c|c|}
\hline \multirow{3}{*}{$\begin{array}{c}\text { Perlakuan } \\
\text { Pengeringan }\end{array}$} & \multicolumn{5}{|c|}{ Kecepatan Tumbuh Benih } \\
\hline & $\begin{array}{l}\mathrm{NaOCl} \\
0 \%\end{array}$ & $\begin{array}{l}\mathrm{NaOCl} \\
6 \%\end{array}$ & $\begin{array}{l}\mathrm{NaOCl} \\
9 \%\end{array}$ & $\begin{array}{l}\mathrm{NaOCl} \\
13 \%\end{array}$ & $\begin{array}{l}\text { Rata- } \\
\text { rata }\end{array}$ \\
\hline & \multicolumn{5}{|c|}{ 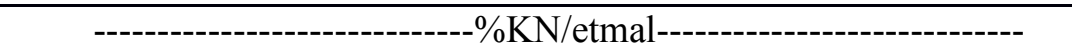 } \\
\hline Kontrol & 58,58 & 55,51 & 65,09 & 51,66 & 57,71 \\
\hline Alami & 55,30 & 47,61 & 77,73 & 51,17 & 57,95 \\
\hline Oven & 52,15 & 52,06 & 61,94 & 43,24 & 52,35 \\
\hline Rata-rata & $55,34^{\mathrm{b}}$ & $51,72^{\mathrm{b}}$ & $68,25^{\mathrm{a}}$ & $48,69^{\mathrm{b}}$ & \\
\hline
\end{tabular}

Keterangan : Superskrip yang berbeda pada baris rata-rata menunjukkan berbeda nyata $(\mathrm{p}<0,05)$.

mempengaruhi daya berkecambah benih. $\mathrm{NaOCl}$ mampu membersihkan pulp yang menempel pada biji tomat. Pulp tomat mengandung asam askorbat yang mampu menghambat perkecambahan benih. Hal ini didukung oleh Karavina dkk. (2009) bahwa $\mathrm{NaOCl}$ dapat meningkatkan kebersihan benih dari pulp. Kandungan klorida pada $\mathrm{NaOCl}$ mampu melepaskan pulp dari biji tomat. Hal ini didukung oleh Kartasapoetra (2003) yang menyatakan bahwa $\mathrm{NaOCl}$ mampu menghilangkan zat penghambat perkecambahan yang terdapat pada pulp yang melapisi biji tomat sehingga dapat meningkatkan daya berkecambah. Semakin sedikit pulp yang melengket pada benih semakin cepat perkecambahannya.
Ardiansyah (2014) menyatakan bahwa tinggi rendahnya kecepatan tumbuh benih berhubungan dengan tinggi rendahnya daya kecambah. Semakin tinggi daya kecambah maka semakin tinggi pula kecepatan tumbuh benih demikian sebaliknya. Teknik ekstraksi benih dengan konsentrasi $\mathrm{NaOCl}$ 9\% adalah dosis yang mampu meningkatkan kecepatan tumbuh benih dibandingkan dengan dosis $13 \%$ yang menyebabkan banyak benih tidak berkecambah. Hal ini dikarenakan kepekatan $\mathrm{NaOCl} 9 \%$ sesuai dengan kebutuhan saat proses ekstraksi sehingga tidak menyebabkan kerusakan pada benih. Hal ini didukung oleh Kartasapoetra (2003) yang menyatakan bahwa pencucian benih dengan $\mathrm{NaOCl}$ mampu menghilangkan zat penghambat (asam askorbat) perkecambahan yang 
terdapat pada pulp yang melapisi biji tomat. Avivi (2005) juga menambahkan bahwa selama perendaman benih, $\mathrm{NaOCl}$ berfungsi juga sebagai desinfektan sehingga selama perkecambahan benih terhindar dari patogen dan mengurangi kemungkinan benih busuk.

\section{Potensi Tumbuh Maksimal}

Hasil analisis ragam menunjukkan bahwa faktor pengeringan berpengaruh nyata terhadap potensi tumbuh maksimal benih tomat dan konsentrasi $\mathrm{NaOCl}$ tidak berpengaruh nyata terhadap potensi tumbuh maksimal benih tetapi tidak terdapat interaksi antara kedua faktor. Data pengaruh pengeringan dan perendaman benih dengan konsentrasi $\mathrm{NaOCl}$ dapat dilihat pada Tabel 3.

Tabel 3 menunjukkan bahwa potensi tumbuh maksimal pada pengeringan metode kontrol dan alami lebih tinggi dibandingkan metode oven. Hal ini menunjukkan bahwa pengeringan mendukung penyerapan air terhambat karena kulit benih yang mengeras dan pada akhirnya menyebabkan kematian embrio benih. Rahayu dkk. (2014) menyatakan bahwa potensi tumbuh maksimal benih dipengaruhi oleh jumlah benih berkecambah. Semakin banyak benih berkecambah maka potensi tumbuh benih juga semakin tinggi demikian sebaliknya.

\section{Jumlah Daun}

Hasil analisis ragam menunjukkan bahwa perlakuan pengeringan berpengaruh nyata terhadap jumlah daun bibit tomat dan faktor konsentrasi berpengaruh nyata terhadap jumlah daun bibit tomat tetapi tidak terdapat interaksi antara kedua faktor. Data pengaruh metode pengeringan dan perendaman benih dengan konsentrasi $\mathrm{NaOCl}$ dapat dilihat pada Tabel 4.

Berdasarkan hasil uji lanjut duncan diketahui bahwa metode pengeringan secara alami dan metode oven memiliki jumlah daun lebih tinggi

Tabel 3. Potensi Tumbuh Maksimal Benih Tomat dengan Perlakuan berbagai Dosis $\mathrm{NaOCl}$ dan Metode Pengeringan

\begin{tabular}{cllccc}
\hline \hline \multirow{2}{*}{$\begin{array}{c}\text { Perlakuan } \\
\text { Pengeringan }\end{array}$} & \multicolumn{5}{c}{ Potensi Tumbuh Maksimal Benih } \\
\cline { 2 - 6 } & $\mathrm{NaOCl}$ & $\mathrm{NaOCl}$ & $\mathrm{NaOCl}$ & $\mathrm{NaOCl}$ & \multirow{2}{*}{ Rata-rata } \\
& $0 \%$ & $--0 \%$ & $13 \%$ & \\
\hline \multirow{2}{*}{ Kontrol } & 90,00 & 93,00 & 95,00 & 97,00 & $94,00^{\mathrm{a}}$ \\
Alami & 91,33 & 95,33 & 99,33 & 86,00 & $93,00^{\mathrm{a}}$ \\
Oven & 72,66 & 80,00 & 57,33 & 68,00 & $69,50^{\mathrm{b}}$ \\
\hline Rata-rata & 84,66 & 89,33 & 83,77 & 83,78 & \\
\hline
\end{tabular}

Keterangan : Superskrip yang berbeda pada kolom rata-rata menunjukkan berbeda nyata $(\mathrm{p}<0,05)$.

viabilitas benih tomat sehingga membantu dalam proses perkecambahan. Pengeringan menggunakan oven menyebabkan potensi tumbuh benih rendah karena terdapat benih tidak berkecambah saat pengamatan. Hal ini diduga karena suhu pengeringan saat pengovenan terlalu tinggi yang menyebabkan benih menjadi keras (hard seed) sehingga pada waktu dikecambahkan benih tidak dapat berimbibisi. Hal ini didukung oleh Kuswanto (2003) yang menyatakan bahwa pengeringan pada suhu tinggi mengakibatkan benih menjadi keras dan imbibisi yaitu dibandingkan tanpa pengeringan (kontrol). Hasil pengeringan secara kontrol adalah 6,08 sementara pengeringan secara alami adalah 6,83 dan pengeringan menggunakan oven 6,84 . Namun jika dilihat dari angka faktor pengeringan benih tomat tidak terlalu memberikan pengaruh besar terhadap jumlah daun bibit tomat. Jumlah daun dapat dipengaruhi faktor pertumbuhan benih tomat. Sesuai dengan pendapat Rasyad (2010) yang menyatakan bahwa faktor pertumbuhan adalah genetik, hormon dan lingkungan. Faktor-faktor tersebut mendukung pertumbuhan normal dan 
Tabel 4. Jumlah Daun Bibit Tomat dengan perlakuan berbagai Dosis $\mathrm{NaOCl}$ dan Metode Pengeringan

\begin{tabular}{|c|c|c|c|c|c|}
\hline \multirow[b]{2}{*}{ Perlakuan Pengeringan } & \multicolumn{5}{|c|}{ Jumlah Daun Bibit } \\
\hline & $\begin{array}{l}\mathrm{NaOCl} \\
0 \%\end{array}$ & $\begin{array}{l}\mathrm{NaOCl} \\
6 \%\end{array}$ & $\begin{array}{l}\mathrm{NaOCl} \\
9 \%\end{array}$ & $\begin{array}{l}\mathrm{NaOCl} \\
13 \%\end{array}$ & $\begin{array}{l}\text { Rata- } \\
\text { rata }\end{array}$ \\
\hline & & ------ & $\mathrm{i} /$ Tanam & $\ldots$ & ----- \\
\hline Kontrol & 4,00 & 6,33 & 8,00 & 7,00 & $6,08^{b}$ \\
\hline Alami & 5,00 & 7,33 & 7,53 & 6,66 & $6,83^{\mathrm{a}}$ \\
\hline Oven & 6,26 & 7,13 & 6,06 & 6,00 & $6,84^{\mathrm{a}}$ \\
\hline Rata-rata & $5,55^{\mathrm{b}}$ & $6,99^{\mathrm{a}}$ & $7,00^{\mathrm{a}}$ & $6,88^{\mathrm{a}}$ & \\
\hline
\end{tabular}

Keterangan : Superskrip yang berbeda pada kolom atau baris rata-rata menunjukkan berbeda nyata $(p<0,05)$.

pembentukan organ-organ tanaman. Benih tomat perlakuan kontrol lebih lambat dibandingkan pengeringan alami dan oven sehingga saat pengamatan jumlah daun tingkat kedewasaan bibit tomat berbeda-beda. Hal ini didukung oleh Surtinah (2007) yang menyatakan bahwa pertumbuhan mempengaruhi jumlah daun karena tanaman yang telah dewasa memiliki daun yang lebih banyak daripada tanaman yang baru bertumbuh sehingga memiliki kondisi daun tanaman yang berbeda.

Konsentrasi $\mathrm{NaOCl}$ berpengaruh nyata terhadap parameter jumlah daun bibit tomat. Perendaman benih tomat dengan dosis $9 \%$ memiliki jumlah daun tertinggi dibandingkan kontrol, perendaman $6 \%$ dan 13\%. Perlakuan $\mathrm{NaOCl} 0 \%$ adalah hasil paling rendah dan berbeda nyata dengan perlakuan $\mathrm{NaOCl} 6 \%$, 9\% dan $13 \%$. Benih ini saat ditanam tidak mendapat perlakuan perendaman $\mathrm{NaOCl}$ sehingga pulp yang masih melekat pada biji tomat menghambat proses tumbuhnya plumula. Hal ini mengakibatkan pertumbuhan bibit tomat lebih lama dibanding tanaman lain. Pernyataan ini didukung oleh Supriyadi (2010) yang menyatakan bahwa lendir tomat mengandung asam askorbat (ABA) yang mampu menghambat (inhibitor) pertumbuhan benih. Keadaan pertumbuhan tanaman ini menyebabkan organ vegetatif tanaman lebih sedikit. Selain itu faktor lain juga mempengaruhi vegetatif tanaman adalah cahaya, suhu, air. Proses fotosintesis yang merupakan reaksi metabolisme pembentukan karbohidrat bergantung sepenuhnya kepada cahaya matahari, sementara poses fotosintesis pada tanaman terjadi di daun. Fauzah (2014) menyatakan sebagai organ penting, daun bertanggung jawab terhadap penerimaan dan penyerapan cahaya untuk proses fotosintesis. Seterusnya, semakin giat kegiatan fotosintesis, maka semakin tinggi fotosintat yang terbentuk. Fotosintat berupa karbohidrat menentukan mutu pertumbuhan tanaman. Hal ini didukung oleh Jumin (2008) yang menyatakan daun dan keadaan daun sangat menentukan jumlah dan mutu suatu tanaman.

\section{Luas Daun}

Hasil analisis ragam menunjukkan bahwa metode pengeringan dan konsentrasi $\mathrm{NaOCl}$ berpengaruh nyata terhadap luas daun dan terdapat interaksi antara metode pengeringan dan konsentrasi $\mathrm{NaOCl}$ terhadap luas daun bibit tomat. Data pengaruh metode pengeringan dan perendaman benih dengan konsentrasi $\mathrm{NaOCl}$ dapat dilihat pada Tabel 5 .

Berdasarkan Tabel 5 diketahui bahwa terdapat interaksi antara faktor pengeringan dan perendaman $\mathrm{NaOCl}$. Interaksi antara pengeringan secara alami dan perendaman $\mathrm{NaOCl} 9 \%$ menunjukkan hasil tertinggi yaitu $154,74 \mathrm{~cm}$. Pertumbuhan tanaman pada perlakuan interaksi ini lebih cepat dibanding perlakuan lain, sehingga pertumbuhan organ vegetatifnya juga lebih banyak. Tanaman yang memiliki luas daun lebih banyak menunjukkan pertumbuhan yang lebih cepat. Hal ini didukung Rudi (2012) yang menyatakan bahwa luas daun menjadi penentu utama kecepatan pertumbuhan tanaman karena metabolisme tanaman yang didapat dari proses fotosintesis semakin banyak, sehingga mampu memenuhi kebutuhan tanaman untuk bertumbuh. 
Tabel 5. Anova dan Uji DMRT Luas Daun Bibit Tomat dengan perlakuan berbagai Dosis NaOCl dan Metode Pengeringan

\begin{tabular}{clllll}
\hline \hline \multirow{3}{*}{ Perlakuan Pengeringan } & \multicolumn{5}{c}{ Luas Daun Bibit } \\
\cline { 2 - 6 } & $\mathrm{NaOCl}$ & $\mathrm{NaOCl}$ & $\mathrm{NaOCl}$ & $\mathrm{NaOCl}$ & \multirow{2}{*}{ Rata-rata } \\
\cline { 2 - 6 } & $0 \%$ & $6 \%$ & $9 \%$ & $13 \%$ & \\
\cline { 2 - 6 } Kontrol & $121,98^{\text {cde }}$ & $125,34^{\text {bcd }}$ & $120,52^{\text {d-e }}$ & $118,77^{\mathrm{e}}$ & $105,91^{\mathrm{b}}$ \\
Alami & $125,76^{\text {bcde }}$ & $136,76^{\mathrm{b}}$ & $154,74^{\mathrm{a}}$ & $131,71^{\text {bcde }}$ & $123,33^{\mathrm{a}}$ \\
Oven & $130,62^{\text {bcde }}$ & $135,61^{\text {b-c }}$ & $132,46^{\text {bcd }}$ & $133,29^{\text {b-c }}$ & $117,60^{\mathrm{a}}$ \\
\hline Rata-rata & $120,57^{\mathrm{a}}$ & $105,37^{\mathrm{b}}$ & $129,24^{\mathrm{a}}$ & $107,26^{\mathrm{b}}$ & \\
\hline
\end{tabular}

Keterangan : • Superskrip yang berbeda pada kolom atau baris rata-rata menunjukkan berbeda nyata $(\mathrm{p}<0,05)$.

- Superskrip yang berbeda pada kolom interaksi menujukkan perbedaan yang nyata $(\mathrm{p}<0,05)$.

Haerul (2015) juga menambahkan bahwa tanaman yang mempunyai daun-daun yang luas dan yang lebih banyak akan mempunyai pertumbuhan yang lebih cepat.

\section{Tinggi Tanaman}

Hasil analisis ragam menunjukkan bahwa konsentrasi $\mathrm{NaOCl}$ berpengaruh nyata terhadap pertumbuhan tinggi tanaman dan faktor pengeringan tidak berpengaruh nyata terhadap tinggi tanaman serta tidak terdapat interaksi antara kedua faktor tersebut. Data pengaruh metode pengeringan dan perendaman benih dengan konsentrasi $\mathrm{NaOCl}$ dapat dilihat pada Tabel 6 .

Tinggi tanaman pada perendaman benih dengan dosis $\mathrm{NaOCl} 9 \%$ yaitu $6,36 \mathrm{~cm}$ yang merupakan hasil tertinggi dibandingkan dengan perlakuan kontrol, $6 \%$ dan $13 \%$. Tinggi tanaman merupakan salah satu parameter vegetatif tanaman. Rismunandar (2001) menyatakan bahwa tinggi tanaman merupakan salah satu parameter yang digunakan untuk mengetahui pertumbuhan vegetatif tanaman. Kecepatan tumbuh sangat mempengaruhi organ vegetatif tanaman. Kecepatan tumbuh benih perlakuan $\mathrm{NaOCl}$ 9\% lebih cepat sehingga memiliki organ vegetatif yang lebih banyak dibanding tanaman pada perlakuan lainnya. Hidayat (2004) menyatakan bahwa kecepatan tumbuh tanaman berbanding lurus dengan pertumbuhan vegetatif tanaman. Pertumbuhan tanaman yang cepat menyebabkan struktur organ vegetatif tanaman juga cepat terbentuk yang dibantu oleh faktor lingkungan seperti suhu, cahaya dan kelembapan.

\section{Laju Pertumbuhan Tanaman}

Berdasarkan hasil analisis ragam diketahui bahwa faktor pengeringan berpengaruh nyata

Tabel 6. Tinggi Tanaman Bibit Tomat dengan perlakuan berbagai Dosis $\mathrm{NaOCl}$ dan Metode Pengeringan

\begin{tabular}{|c|c|c|c|c|c|}
\hline \multirow[b]{2}{*}{ Perlakuan Pengeringan } & \multicolumn{5}{|c|}{ Tinggi Tanaman Bibit } \\
\hline & $\begin{array}{l}\mathrm{NaOCl} \\
0 \% \\
\end{array}$ & $\begin{array}{l}\mathrm{NaOCl} \\
6 \% \\
\end{array}$ & $\begin{array}{l}\mathrm{NaOCl} \\
9 \% \\
\end{array}$ & $\begin{array}{l}\mathrm{NaOCl} \\
13 \% \\
\end{array}$ & $\begin{array}{l}\text { Rata- } \\
\text { rata }\end{array}$ \\
\hline Kontrol & 5,32 & 6,06 & $\begin{array}{l}-----c m- \\
5.76\end{array}$ & 5.57 & 5.68 \\
\hline Alami & 5,00 & 6,65 & 7,14 & 5,35 & 6,04 \\
\hline Oven & 5,90 & 6,25 & 6,17 & 5,81 & 6,03 \\
\hline Rata-rata & $5,41^{\mathrm{b}}$ & $6,32^{\mathrm{a}}$ & $6,36^{\mathrm{a}}$ & $5,58^{\mathrm{b}}$ & \\
\hline
\end{tabular}

Keterangan : Superskrip yang berbeda pada baris rata-rata menunjukkan berbeda nyata $(\mathrm{p}<0,05)$. 
terhadap laju pertumbuhan bibit tomat dan konsentrasi $\mathrm{NaOCl}$ berpengaruh nyata terhadap laju pertumbuhan bibit tomat tetapi tidak terdapat interaksi antara kedua faktor tersebut. Data pengaruh metode pengeringan dan perendaman benih dengan konsentrasi $\mathrm{NaOCl}$ dapat dilihat pada Tabel 7. pertumbuhannya lebih cepat dibandingkan perlakuan lain. Besarnya laju tumbuh tanaman juga dipengaruhi oleh lingkungan, berat kering daun dan luas daun. Sesuai dengan pendapat Johnson (2003) bahwa laju tumbuh tanaman akan tetap meningkat dengan meningkatnya indeks luas daun hingga nilai tertentu selama daun bagian

Tabel 7. Laju Pertumbuhan Bibit Tomat dengan perlakuan berbagai Dosis $\mathrm{NaOCl}$ dan Metode Pengeringan

\begin{tabular}{clllll}
\hline \hline \multirow{2}{*}{$\begin{array}{c}\text { Perlakuan } \\
\text { Pengeringan }\end{array}$} & \multicolumn{5}{c}{ Laju Pertumbuhan Bibit } \\
\cline { 2 - 6 } & $\mathrm{NaOCl}$ & $\mathrm{NaOCl}$ & $\mathrm{NaOCl}$ & $\mathrm{NaOCl}$ & $\begin{array}{l}\text { Rata- } \\
\text { rata }\end{array}$ \\
\cline { 2 - 6 } & \multicolumn{2}{c}{------------ - } & $9 \%$ & $13 \%$ & $1,83^{\mathrm{b}}$ \\
Kontrol & 1,75 & 2,51 & 1,61 & 1,47 & $3,98^{\mathrm{a}}$ \\
Alami & 3,39 & 3,55 & 7,41 & 1,59 & $3,38^{\mathrm{a}}$ \\
Oven & 3,30 & 3,27 & 5,31 & 1,64 & \\
\hline Rata-rata & $2,82^{\mathrm{b}}$ & $3,11^{\mathrm{b}}$ & $4,77^{\mathrm{a}}$ & $1,57^{\mathrm{b}}$ & \\
\hline
\end{tabular}

Keterangan : Superskrip yang berbeda pada kolom atau baris rata-rata menunjukkan berbeda nyata $(\mathrm{p}<0,05)$.

Berdasarkan Tabel 7 diketahui bahwa laju pertumbuhan bibit tomat pada perlakuan tanpa pengeringan (kontrol) berbeda nyata dengan pengeringan metode alami dan metode oven. Perlakuan tanpa pengeringan (kontrol) lebih rendah yaitu 1,83 dibandingkan pengeringan secara alami dan oven yaitu 3,98 dan 3,38 . Hal ini karena pertumbuhan tanaman pada perlakuan ini lebih lambat sehingga pertambahan bobot kering tanaman hasil akumulasi tinggi tanaman, jumlah daun dan akar lebih sedikit. Rudi (2012) menyatakan bahwa laju pertumbuhan tanaman adalah bertambahnya berat kering tanaman dalam satuan waktu. Adnyesuari (2015) menambahkan bahwa bahan kering tanaman merupakan gambaran dari translokasi hasil fotosintesis (fotosintat) ke seluruh bagian tanaman sehingga dapat dikatakan laju tumbuh tanaman sangat ditentukan oleh pertumbuhan generatif tanaman terkhusus daun yang berperan sebagai tempat perubahan hasil fotosintesis.

Konsentrasi $\mathrm{NaOCl}$ berpengaruh nyata terhadap laju pertumbuhan bibit tomat. Ekstraksi benih tomat dengan perendaman $\mathrm{NaOCl}$ dengan dosis $9 \%$ berbeda nyata dengan perendaman kontrol, $6 \%$ dan $13 \%$. Perendaman dengan dosis $9 \%$ adalah hasil terbaik yaitu 4,77 . Hal ini karena bawah menerima cukup radiasi matahari untuk fotosintesis dan mengimbangi respirasi.

\section{Laju Pertumbuhan Relatif}

Hasil analisis ragam menunjukkan bahwa faktor metode pengeringan berpengaruh nyata terhadap laju pertumbuhan relatif bibit tanaman, faktor konsentrasi $\mathrm{NaOCl}$ tidak berpengaruh nyata terhadap laju pertumbuhan relatif bibit tomat dan tidak terdapat interaksi antara kedua faktor tersebut. Data pengaruh metode pengeringan dan perendaman benih konsentrasi $\mathrm{NaOCl}$ dapat dilihat pada Tabel 8.

Berdasarkan Tabel 8 diketahui bahwa parameter laju pertumbuhan relatif dengan pengeringan secara alami lebih tinggi dibandingkan metode pengeringan lainnya. Hal ini karena pertumbuhan tanaman dengan pengeringan alami lebih cepat dibanding tanaman lain sehingga memiliki organ vegetatif tanaman yang lebih banyak. Suharti dkk. (2014) menyatakan bahwa suatu perlakuan memberikan pengaruh pertumbuhan yang berbeda-beda terhadap tanaman. Selain itu Avivi (2005) juga menyatakan tingkat kedewasaan tanaman mempengaruhi pertumbuhan organ tanaman, semakin dewasa 
Tabel 8. Laju Pertumbuhan Relatif Bibit Tomat dengan perlakuan berbagai Dosis $\mathrm{NaOCl}$ dan Metode Pengeringan

\begin{tabular}{|c|c|c|c|c|c|}
\hline \multirow[b]{2}{*}{ Perlakuan Pengeringan } & \multicolumn{5}{|c|}{ Laju Pertumbuhan Relatif } \\
\hline & Kontrol & $\begin{array}{l}\mathrm{NaOCl} \\
6 \%\end{array}$ & $\begin{array}{l}\mathrm{NaOCl} \\
9 \%\end{array}$ & $\begin{array}{l}\mathrm{NaOCl} \\
13 \%\end{array}$ & $\begin{array}{l}\text { Rata- } \\
\text { rata }\end{array}$ \\
\hline & & & $/ \mathrm{g} /$ ming & -----. & \\
\hline Kontrol & 1,91 & 1,67 & 1,90 & 1,60 & $1,56^{\mathrm{b}}$ \\
\hline Alami & 1,38 & 1,58 & 1,63 & 1,65 & $1,77^{\mathrm{a}}$ \\
\hline Oven & 1,77 & 1,58 & 1,66 & 1,58 & $1,64^{\mathrm{ab}}$ \\
\hline Rata-rata & 1,68 & 1,61 & 1,73 & 1,62 & \\
\hline
\end{tabular}

Keterangan : Superskrip yang berbeda pada kolom rata-rata menunjukkan berbeda nyata $(\mathrm{p}<0,05)$.

tanaman maka organ tanaman juga semakin banyak.

Laju pertumbuhan relatif tanaman menurut Anggraito (2004) merupakan peningkatan berat kering tanaman dalam suatu interval waktu, erat hubungannya dengan berat awal tanaman. Laju pertumbuhan relatif tanaman pada setiap perlakuan ini berbeda-beda. Perbedaan tersebut dikarenakan tingkat pertumbuhan tanaman yang tidak sama, dapat disebabkan lingkungan, genetik atau keadaan benih awal. Menurut Utami (2007) perbedaan laju pertumbuhan relatif tanaman dapat disebabkan perbedaan hasil fotosintat setiap tanaman yang mempengaruhi jumlah nitrogen. Mangoendidjojo (2003) menambahkan luas daun sangat erat kaitannya dengan laju pertumbuhan relatif tanaman. Perlakuan ini memiliki luas daun tertinggi sehingga memiliki laju pertumbuhan relatif yang tinggi pula karena cahaya matahari yang ditangkap oleh klorofil melalui proses fotosintesis akan menghasilkan bahan baku yang lebih banyak bagi pertumbuhan dan perkembangan tanaman.

\section{KESIMPULAN}

Interaksi pengeringan dan ekstraksi benih tomat dengan perendaman menggunakan $\mathrm{NaOCl}$ dosis $9 \%$ hanya terjadi pada parameter luas daun. $\mathrm{NaOCl}$ dapat memperbaiki sifat fisik benih tomat yakni mempermudah untuk membersihkan pulp yang melekat pada benih tomat, sehingga mempercepat perkecambahan benih. Pengeringan benih metode alami membantu pengeringan benih tomat dan mendukung perkecambahan dan pertumbuhan bibit tomat meskipun membutuhkan waktu lebih lama dibandingkan metode oven.

\section{DAFTAR PUSTAKA}

Adnyesuari, A. 2015. Induksi partenokarpi pada tiga genotipe tomat dengan GA3. Jurnal Ilmu Pertanian. 18 (1): 56-62.

Anggraito, Y.U. 2004. Identifikasi berat, diameter buah tomat (Lycopersicum annum L) kultivar action akibat perlakuan kolkisin. Junal Agroekoteknologi 10: 37-42.

Ardiansyah, R. 2014. Teknik sterilisasi eksplan dan induksi tunas dalam mikropropagasi tembesu. 5 (3) : 167-173.

Avivi, S. 2005. Pengaruh perlakuan sortasi natrium hipoklorot dan fungisida pada kacang tanah untuk mengeliminasi kontaminasi Aspergilus Flavus. J. HPT Tropika. 5 (1) : 58-65.

Badan Pusat Statistik. 2016. Produksi sayursayuran dan buah-buahan di Indonesia tahun 2014. Diakses tanggal 10 Juli 2017.

Chanan, M. 2004. Pengaruh masa simpan benih terhadap viabilitas lada (Eucalyptus deglupta Blume). J. Tropika. 11 (2) : 215 220.

Dalimartha, S dan A. Felix. 2011. Khasiat buah 
dan sayur. Cetakan ke 2. Penebar Swadaya, Jakarta.

Fauzah, S. 2014. Pengaruh pengeringan terhadap kualitas benih kedelai (Glycine $\max \mathrm{L}$ ). Jurnal Produksi Tanaman. 2 (5) : 388-394.

Hasanah, M. 2002. Peranan mutu fisiologik benih dan pengembangan industri benih tanaman industri. Jurnal Penelitian dan Pengembangan Pertanian. 21 (3): 84-90.

Haerul, M. 2015. Pertumbuhan dan produksi tanaman tomat (Solanum lycopersicum $\mathrm{L}$ ) terhadap POC. J. Agrotan. 1 (2) : $69-80$.

Hidayat, S. 2004. Pendugaan Keragaman Genetik pada Generasi F3 Tanaman Tomat. Fakultas Pertanian. Universitas Gadjah Mada, Yogjakarta.

Iskandar, U. 2008. Respon pertumbuhan eksplan tomat pada pembiakan kultur jaringan terhadap imbangan ZPT auksin dan sitokinin. Jurnal Agritop. 11 : 114-123.

ISTA. 2006. Internasional rules for seed Testing. The International Seed Testing Association (ISTA), Bassersdorf, CHSwitzerland.

Johnson, H. E., D. Broadhurst, dan Smith. 2003. Metaboli Fingerprinting of Salt-Stressed Tomatoes. Phytochemistry 62: 919-928

Jumberi. 2006. Pemanfaatan hara air laut untuk memenuhi kebutuhan tanaman. Balai Pengkajian Teknologi Pertanian. Medan, Sumatra Utara.

Karavina, C. 2009. Assessing the effects of fermentation time on tomato (Lycopersicon lycopersicum Mill) seed viability. Journal of Sustainable Development in Africa. 10 (4) : 106-112.

Kartasapoetra, A. 2003. Teknologi Benih pengolahan Benih dan Tuntunan Praktikum dan Tuntunan Praktikum. Rineka Cipta, Jakarta.
Kuswanto, H. 2003. Teknologi pemprosesan pengemasan dan penyimpanan benih. Kanisius, Yogyakarta.

Mangoendidjojo, W. 2003. Dasar-Dasar Pemuliaan Tanaman. Kanisius, Yogyakarta.

Nyoman, D. 2016. Uji efektivitas teknik ekstraksi dan dry heat treatment terhadap kesehatan bibit tomat (Lycopersicum esculentum Mill). Jurnal Agroekoteknologi. 5 (1) : $2301-6515$.

Rahayu, A., T. Hardiyati dan P. Hidayat. 2014. Pengaruh polyethylene glycol 6000 dan lama penyimpanan terhadap mutu benih kakao (Theobroma cacao L.). Pelita Perkebunan. 30 (1):15-24.

Rasyad, A. dan Idwar. 2010. Interaksi genetik x lingkungan dan stabilitas komponen hasil berbagai genotipe kedelai di provinsi riau. Jurnal Agronomi Indonesia. 38 (1) : 25 29.

Risaketta, S. H. 2006. Teknologi tanaman sayuran buah. Direktorat Budidaya Tanaman Sayuran dan Biofarmaka, Lembang.

Rismunandar, 2001. Tanaman Tomat. Sinar Baru Algensindo, Bandung.

Rudi, H. 2012. Early steps of tomato breeding resist to root-knot nematoda. Jurnal Agrivita. 34 (3) : 126- 537.

Setiawan, A. B. 2015. Pengaruh Giberelin Terhadap Karakter Morfologi dan Hasil Buah Partenokarpi pada Tujuh Genotipe Tomat (Solanum lycopersicum L.). 18 (2) : 69-76.

Suharti, T., Y. Bramasto dan N. Yuniarti. 2014. Pengaruh teknik pengendalian penyakit benih terhadap viabilitas benih tembesu (Fagraea Fagrans Roxb). Jurnal Hutan Tropis. 2 (1) : 60-64. 
Suita E. 2013. Pengaruh sortasi benih terhadap viabilitas dan pertumbuhan bibit akor (Acacia auriculiformis). Jurnal Perbenihan Tanaman Hutan 1 (2): 83-91.

Supriyadi, A. 2010. Pengembangan benih tomat (Lycopersicumesculentum Mill.)

Bersertifikat di UPTD BP2TPH Ngipiksari. Kaliurang, Yogyakarta.

Surtina. 2007. Kajian tentang hubungan pertumbuhan vegetatif dengan produksi tanaman tomat (lycopersicum esculentum, mill ). Jurnal Ilmiah Pertanian. 4 (1) : 2346.

Surahman, M. 2012. Pengaruh Tingkat Kemasakan Buah, Metode Ekstraksi Buah, Metode Pengeringan, Jenis Kemasan, dan Lama Penyimpanan pada Mutu Benih Jarak Pagar (Jatropha curcas). Jurnal Ilmu Pertanian Indonesia. 18 (2) : 73-78.

Tatipata, A., P. Yudono., A. Purwantoro, dan W. Mangoendidjojo. 2004. Kajian aspek fisiologi dan biokimia deteriorasi benih kedelai dalam penyimpanan ilmu pertanian. 11 (2) : 76-87.

Uswah, H. 2009. Respon tanaman tomat (Lycopersicum esculentum Mill) pada awal pertumbuhan terhadap keragaman ukuran agrerat entisol. J. Agronland. 12 (2) : 103-109.

Utami, N.,W. 2007. Aplikasi media tumbuh dan perendaman biji pada perkecambahan jelutung (Dyera costulata Miq. Hook.f). Jurnal Ilmiah Nasional Berita Biologi 8 (4): $291-298$

Wartapa. A., S. Suhartiningsih, S. Astuti, dan Sukadi. 2009. Pengaruh jenis pupuk dan tanaman antagonis terhadap hasil cabe rawit (Capsicum frutescens) Budidaya Vertikultur. Jurnal Ilmu-Ilmu Pertanian 6 (2) : 142- 156.

Widiarti,W. 2016. Respon vigor benih dan pertumbuhan awal tanaman tomat terhadap konsentrasi dan lama perendaman asam klorida ( $\mathrm{HCl})$. Jurnal Agritop. 2 : 15-160.

Wiguna, G. 2013. Perbaikan viabilitas dan kualitas fisik benih cabai melalui pengaturan lama fermentasi dan penggunaan $\mathrm{NaOCl}$ pada saat pencucian benih. Jurnal Mediagro. 2 (2): 68-79.

Zanzibar, M. 2001. Potensi dan teknik budidaya kepuh (Linn) untuk pembangunan hutan rakyat. Info Benih. 6 (1) : 15-22. 